\title{
Neuronal conversion of dermal fibroblasts as a disease model
}

\section{Hastalık modeli olarak dermal fibroblasttan dönüştürülmüş nöron}

\author{
Ekim Zihni TAŞKIRAN'1, Beren KARAOSMANOĞLU' ${ }^{1}$
}

Department of Medical Genetics, Faculty of Medicine, Hacettepe University, Ankara, Turkey.

Corresponding author: Assist. Prof. Ekim Zihni Taşkıran, PhD., Hacettepe University, Faculty of Medicine, Department of Medical Genetics, Ankara, Turkey

E-mail: eztaskiran@hacettepe.edu.tr,ekimtaskiran@gmail.com

Received/Accepted: October 22, 2018 / December 16, 2018

Conflict of interest: There is not a conflict of interest.

\begin{abstract}
SUMMARY
Objective: Disease modelling applications are gaining importance especially for the need of patient-specific studies. Because some cell types cannot be obtained from patients, somatic cell differentiation is needed for disease modelling. There are many methods for somatic cell reprogramming. Induced Pluripotent Stem Cells (iPSCs) and direct conversion are the main techniques. However, due to the disadvantages of iPSCs, such as expense, high mutation rate and differentiation defects, many researches choose direct conversion for reprogramming.

In this study, we aimed to reprogram dermal fibroblasts into neurons with direct conversion in order them to be potentially used for patient-specific disease modelling applications.

Method: Commercially purchased dermal fibroblasts were seeded on coverslips and then induced with a medium containing small chemicals for 24 hours. Cells were visualized by scanning electron microscopy and transcriptome analysis was done by next generation RNA sequencing.
\end{abstract}

Results: Neuronal cell morphology was observed after 24 hour induction. According to the transcriptomic data, neuronal genes were upregulated.

Conclusions: Dermal fibroblasts were successfully induced into neurons by direct conversion with using small chemicals.

Keywords: Dermal fibroblast, disease modelling, direct conversion, neuron, transcriptomics.

ÖZET

Amaç: Kişiselleștirilmiș tıp çalıșmaları için hastalık modeli oluşturmak önem kazanmıștır. Hastalardan bazı hücre türlerinin alınamıyor olması, hastalık modeli için somatik hücre farklılaştırılmasını gerektirmiştir. Hücrelerin yeniden programlanması için pek çok yöntem bulunmaktadır. İndüklenmiş Pluripotent Kök Hücre (iPKH) ve doğrudan dönüştürme en temel iki yöntemdir. Ancak, iPKH'nin pahalılık, yüksek mutasyon oranı ve farklılaşma hasarları gibi dezavantajlarından dolayı, pek çok araştırmacı doğrudan dönüştürmeyi seçmektedir.

Bu çalışmada, dermal fibroblastların doğrudan dönüștürme ile nöronlara farklılaştırılarak kişiye özel hastalık modeli uygulamalarında kullanılabileceği amaçlanmıştır.

Yöntem: Ticari olarak satın alınmış dermal fibroblastlar lamel üzerine ekilerek küçük kimyasallar içeren besiyeri ile 24 saat süresince indüklenmiştir. Hücreler taramalı elektron mikroskobu ile görüntülenmiş ve yeni nesil RNA dizileme ile transkriptom analizi gerçekleştirilmiştir.

Bulgular: 24 saatlik indükleme sonucunda nöral hücre morfolojisi görülmüştür. Transkriptom sonuçlarında nöral genlerin artmış olduğu tespit edilmiştir.

Sonuç: Dermal fibroblastlar küçük moleküller kullanılarak doğrudan dönüştürme ile başarılı olarak indüklenmiştir. 


\section{INTRODUCTION}

For the last decade, disease modelling applications has emerged due to the need for patient-specific studies. Cell lines or animal models may not always reflect the disease phenotype exactly. Therefore, modelling the disease pathogenesis with patient-derived samples are beneficial for future drug research. However, all cell types cannot be obtained from healthy donors or patients, especially needed by the interventional methods. At this stage, differentiation studies become very critical ${ }^{1}$. In detail, differentiating any somatic cell of the patient into a desired cell type plays a key role for disease modelling. There are many techniques to differentiate somatic cells into other types, two of the most popular ones are induced pluripotent stem cells (iPSCs) and direct conversion/reprogramming. iPSCs are firstly achieved by introducing 'Yamanaka factors' (Oct3/4, Sox2, Klf4 and c-Myc) into somatic cells and taking them into pluripotent stage ${ }^{2}$. Direct conversion or reprogramming (DC) is converting

\section{MATERIAL AND METHODS}

\section{Cell Culture}

Primary human dermal fibroblasts (DFs) (Cat. No: PCS-201-012 ${ }^{\mathrm{TM}}$ ) were purchased from American Type Culture Collection (ATCC), which were obtained from a 28 years old male African American donor's abdominal skin (Lot: 63792061). Passage 3 cells were used for further experiments. Cells were incubated at $37^{\circ} \mathrm{C}$ and $5 \%$ $\mathrm{CO}_{2}$, culture medium (DMEM-LG supplemented with 10\% FBS, $1 \%$ Penicillin-streptomycin and $1 \%$ L-glutamine) was changed twice a week.

\section{Neuronal Induction}

Six thousand DFs were seeded per $\mathrm{cm}^{2}$, on coverslips in a multi well plate. Before induction, cells were incubated in a medium (DMEM-LG supplemented with 10\% FBS, 1\% Penicillinstreptomycin, 1\% L-glutamine and 1\% MEM Non-essential aminoacids) for 24 hours. Neuronal induction medium was added after washing with PBS (phosphate buffered saline). Induction medium was prepared according to a recent study ${ }^{7}$, details were given below:

DMEM F12 : Neurobasal Medium (1:1) (DN) was mixed; bFGF (100ug/ml), B27 (50X in DN) a somatic cell into another cell type by using exogenic molecules (transcription factors, small chemicals etc.), without forcing them to go to a pluripotent stage ${ }^{3}$. When compared to DC, iPSCs require more time and expense, cells could gain de novo mutations in iPSCs production process ${ }^{4}$, age-related gene expression may be affected due to the hypermethylation ${ }^{5}$ and forms teratomas. In addition, iPSCs process can generate differentiation defective iPSCs which cannot differentiate into neurons ${ }^{6}$. However, DC is more easy and cheaper, conserves age-related gene expression, has nearly $100 \%$ conversion efficiency and does not form any cancerous or differentiation defective cells 5 . Therefore, differentiating cells with DC is more beneficial for cell differentiation studies. In this study, we differentiate dermal fibroblasts into neurons by using small chemicals and investigate the global gene expression differences between these two cell types.

N2 (100X in DN), Penicillin/streptomycin (100X), and the small chemicals [VPA (50mM), CHIR99021 (10mM), Repsox (10mM), Forskolin (50mM), SP600125 (50mM), GÖ6983 (10mM) and Y-27632 (10mM)] were added.

\section{Scanning Electron Microscopy (SEM)}

Culture medium was removed, cells were washed with PBS and were fixated with $2.5 \%$ glutaraldehyde for 15 minutes. For drying, fixated samples were treated with $50 \%, 75 \%, 90 \%, 95 \%$ and $100 \%$ ethanol sequentially, for 5 minutes each. Then, $75 \mu \mathrm{l}$ Hexamethylenedisilazane (HMDS) was dropped. Dried samples were coated with gold/palladium (1:1) with sputter, carbon and e-beam coater (Leica EM ACE600). Then visualized under SEM (Tescan, GAIA3).

\section{RNA Isolation and RNA-Sequencing}

After 24 hour induction, culture medium was removed and washed with PBS. Total RNA from cultured cells was extracted using TRIzol (Sigma). SENSE mRNA kit for Ion Torrent (Lexogen) was used for strand-specific library preparation. Briefly, $1000 \mathrm{ng}$ total RNA was enriched for poly(A) mRNAs using oligo-dT magnetic beads. For random hybridization of starter/stopper heterodimers, RNA/magnetic beads mixes were incubated on $37^{\circ} \mathrm{C}$ for 2 hours. Then, first and second strand cDNA synthesis was 
performed. After library amplification libraries were quantified with Qubit 2.0 Fluorometer (Thermo Fisher Scientific). Clonal amplification of the libraries (emulsion PCR) was performed on Ion OneTouch ${ }^{\mathrm{TM}} 2$ system using the Ion PI Hi-Q OT2 $200 \mathrm{Kit}$ and Ion sphere particles (ISP) were enriched using the One Touch ${ }^{\mathrm{TM}}$ ES module, according to the manufacturer's instructions. Finally, ISPs were loaded on Ion PI chips v.3 and sequenced by using Ion Proton Sequencer (Thermo Fisher Scientific). For data analysis, sequencing reads were mapped by using TMAP (Torrent Mapping Alignment Program) which runs on the Ion Torrent Server. Then, pathway analysis was done using STRING web tool (https://string-db.org/).

\section{RESULTS}

When dermal fibroblasts are cultured at induction medium they undergo neural differentiation (Figure 1). Morphological characteristics of neurons were appeared in cell culture in the first 12 hours. We observed unipolar-, bipolar- and multipolar-like neural cells. The neural network was observed at 18 hours. At the 48 hours of induction, most of the cells undergone differentiation.

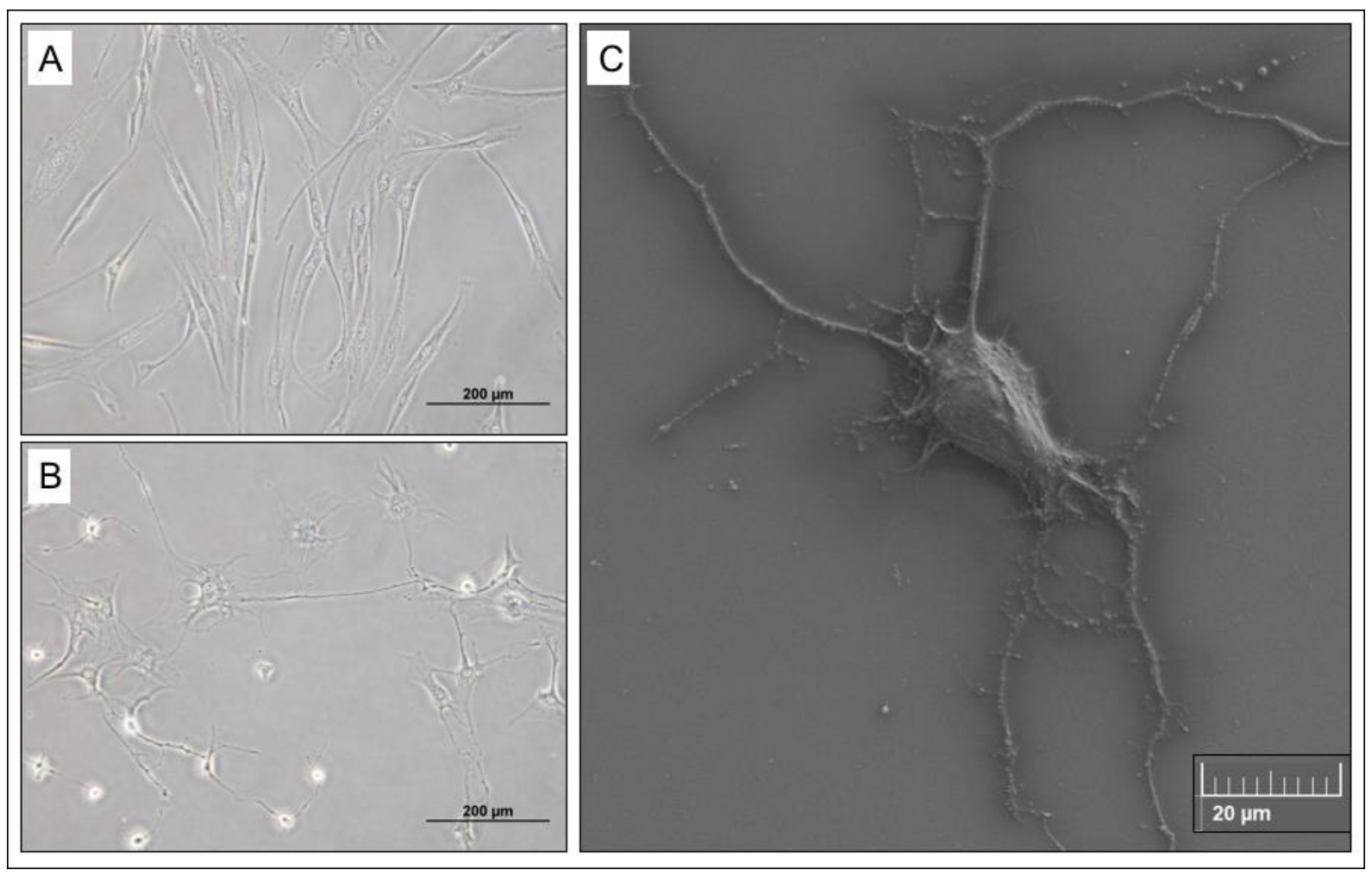

Figure: Microscopic images of the cells. A. light microscopy of dermal fibroblast, B. light microscopy of 24 hour induced neurons, C. Scanning Electron Microscopy (SEM) of 24 hour induced neurons.

In order to analyze the gene expression profile of these cells we performed total mRNA sequencing. We focused on the $24^{\text {th }}$ hour of induction so that we could investigate the early changes of global gene expression between dermal fibroblasts and induced cells. Comparative analysis showed that 1291 genes were up-regulated (minimum 4-fold) after neuronal induction. Addition to this, 785 genes were relatively increased in induced cells compared to dermal fibroblasts. We performed pathway analysis using STRING with these totally nearly 2000 genes (Gene list is available upon request). We obtained GO annotation of induction-related genes in two domains. We showed that that several pathways were closely related to neuronal cells according to biological process (Table 1). 
Table 1: Pathway analysis according to biological process.

\begin{tabular}{|c|c|c|c|}
\hline Pathway ID & Pathway Description & $\begin{array}{c}\text { Observed Gene } \\
\text { Count }\end{array}$ & $\begin{array}{c}\text { False Discovery } \\
\text { Rate }\end{array}$ \\
\hline GO.0071840 & cellular component organization or biogenesis & 464 & $1.83 \mathrm{e}-06$ \\
\hline GO.0032502 & developmental process & 441 & $4.33 \mathrm{e}-05$ \\
\hline GO.0044237 & cellular metabolic process & 713 & 0.000277 \\
\hline GO.0048856 & anatomical structure development & 388 & 0.000277 \\
\hline GO.0048869 & cellular developmental process & 314 & 0.000657 \\
\hline GO.0030182 & neuron differentiation & 117 & 0.000663 \\
\hline GO.0048666 & neuron development & 100 & 0.000852 \\
\hline GO.0030154 & cell differentiation & 299 & 0.00123 \\
\hline GO.0050790 & regulation of catalytic activity & 224 & 0.00125 \\
\hline GO.0050803 & regulation of synapse structure or activity & 37 & 0.00242 \\
\hline GO.0050804 & modulation of synaptic transmission & 41 & 0.00242 \\
\hline GO.0048701 & embryonic cranial skeleton morphogenesis & 12 & 0.0179 \\
\hline GO.0016070 & RNA metabolic process & 321 & 0.019 \\
\hline GO.0007411 & axon guidance & 52 & 0.0196 \\
\hline GO.0045595 & regulation of cell differentiation & 149 & 0.0199 \\
\hline GO.0061564 & axon development & 63 & 0.0202 \\
\hline GO.0007409 & axonogenesis & 61 & 0.0212 \\
\hline GO.0000904 & cell morphogenesis involved in differentiation & 77 & 0.0229 \\
\hline GO.0006836 & neurotransmitter transport & 25 & 0.0229 \\
\hline
\end{tabular}

Addition to this, we observed neuron-related genes controlling several cellular components (Table 2). The most increased top 30 genes were given in Table 3. Most of them are primarily related to a neuronal function. 
Table 2: Pathway analysis according to cellular components.

\begin{tabular}{|c|c|c|c|}
\hline Pathway ID & Pathway Description & $\begin{array}{c}\text { Observed Gene } \\
\text { Count }\end{array}$ & $\begin{array}{c}\text { False Discovery } \\
\text { Rate }\end{array}$ \\
\hline GO.0030054 & cell junction & 138 & $2.44 \mathrm{e}-06$ \\
\hline GO.0043233 & organelle lumen & 395 & 0.000171 \\
\hline GO.0012505 & endomembrane system & 339 & 0.000619 \\
\hline GO.0044432 & endoplasmic reticulum part & 123 & 0.00123 \\
\hline GO.0005634 & nucleus & 597 & 0.00295 \\
\hline GO.0097458 & neuron part & 122 & 0.00299 \\
\hline GO.0044421 & extracellular region part & 349 & 0.00363 \\
\hline GO.0005783 & endoplasmic reticulum & 163 & 0.00496 \\
\hline GO.0005578 & proteinaceous extracellular matrix & 47 & 0.00712 \\
\hline GO.0030055 & cell-substrate junction & 51 & 0.00894 \\
\hline GO.0005925 & focal adhesion & 50 & 0.00939 \\
\hline GO.0031982 & vesicle & 331 & 0.0148 \\
\hline GO.0005912 & adherens junction & 55 & 0.0155 \\
\hline GO.0005739 & mitochondrion & 164 & 0.0171 \\
\hline GO.0098793 & presynapse & 24 & 0.0171 \\
\hline GO.0070161 & anchoring junction & 56 & 0.0194 \\
\hline GO.0043005 & neuron projection & 94 & 0.0207 \\
\hline GO.0036477 & somatodendritic compartment & 71 & 0.0236 \\
\hline GO.0009986 & cell surface & 79 & 0.0308 \\
\hline GO.0005730 & nucleolus & 93 & 0.0353 \\
\hline GO.0045202 & synapse & 72 & 0.0371 \\
\hline GO.0043025 & neuronal cell body & 50 & 0.0475 \\
\hline
\end{tabular}


Table 3: The most increased 30 genes after 24 hour neuronal induction.

\begin{tabular}{|c|c|c|c|}
\hline Gene Name & Fold Change (Increase) & Function/Location & Reference \\
\hline AC005682.6 & 83,59 & & \\
\hline GPHN & 78,95 & $\begin{array}{c}\text { Component of the postsynaptic } \\
\text { protein network }\end{array}$ & 10 \\
\hline RP11-115D19.1 & 77,78 & - & - \\
\hline GCK & 52,24 & - & - \\
\hline THRB-AS1 & 49,92 & - & - \\
\hline BCAN & 47,87 & Neural proteoglycan & 11 \\
\hline EGFLAM & 44,37 & Localized at the ribbon synapses & 12 \\
\hline EIF2B2 & 42,95 & $\begin{array}{l}\text { Guanine nucleotide exchange factor } \\
\text { activity of EIF2B }\end{array}$ & 13 \\
\hline RP11-104H15.8 & 38,53 & - & - \\
\hline CDC7 & 38,31 & - & - \\
\hline LINC00880 & 36,65 & - & - \\
\hline PDE2A & 35,99 & Phosphodiesterase & 14 \\
\hline FER1L6-AS2 & 35,72 & - & - \\
\hline FARP1 & 35,63 & $\begin{array}{l}\text { Dendritic filopodial dynamics in } \\
\text { immature neurons }\end{array}$ & 15 \\
\hline RP11-501J20.5 & 33,86 & - & - \\
\hline CTD-2514K5.4 & 33,67 & - & - \\
\hline $\mathrm{KCNV} 2$ & 33,67 & $\begin{array}{l}\text { Regulatory subunit of voltage-gated } \\
\text { potassium channels }\end{array}$ & 16 \\
\hline RP11-21L19.1 & 33,61 & - & - \\
\hline TMEM151B & 32,51 & - & - \\
\hline C9orf69 & 31,35 & - & - \\
\hline STK24 & 31,35 & Regulates axon outgrowth & 17 \\
\hline CTC-441N14.2 & 30,19 & & \\
\hline MAPK8IP1 & 27,86 & $\begin{array}{l}\text { Regulation of autophagosomes } \\
\text { trafficking }\end{array}$ & 18 \\
\hline ALKBH4 & 26,85 & - & - \\
\hline RP1-102K2.6 & 26,85 & - & - \\
\hline RP1-102K2.8 & 26,73 & - & - \\
\hline PHACTR1 & 26,72 & $\begin{array}{c}\text { Expressed in the central nervous } \\
\text { system }\end{array}$ & 19 \\
\hline C9orf9 & 26,70 & - & - \\
\hline RP11-845M18.6 & 26,70 & - & - \\
\hline
\end{tabular}




\section{DISCUSSION}

The use of patient-specific cells for modelling is critical to investigate molecular mechanisms of human diseases. Using reprogramming technologies it is also possible to create in vitro models for neurological diseases 1, 3, 5, 7. Large scale omics data (such as genomics, transcriptomics, and proteomics) has a great power in identifying disease-mechanisms, drug targets and biomarkers in human diseases ${ }^{8}$. Transcriptomics has been one of the most popular approach to obtain global gene expression data ${ }^{9}$. In this study, we try to create neuron-like cells from dermal fibroblasts using direct conversion and investigate molecular differences in transcriptomic level. Because direct conversion has many advantages against other reprogramming methods, we choose this method for reprogramming of dermal fibroblasts. With this purpose, we used a small chemical cocktail for neuronal induction medium and followed them up to 72 hours. Because the most striking change (neuronal cell morphology) was observed at $24^{\text {th }}$ hour, we performed RNA-Seq at that time point. We focused on the increased/up-regulated genes on directly converted neuronal cells. The most increased genes list contains proteins specifically related to neuronal functions. Similar to this, pathway analysis showed strong neuronal signatures in increased/up-regulated genes (nearly 2000 transcripts). Together both gene expression signatures and cellular characteristics showed that neuronal conversion was successful in the first 24 hours of induction.

Future studies should focused on functional capabilities of these directly converted neurons and investigate transcriptomic profiles in different time points in order to enlighten the whole differentiation process in vitro. By doing this, it will be possible to create different cell types of neuronal lineage. Additional studies with omic platforms (such as proteomics and metabolomics) might contribute to investigate the differentiation process in detail. In the age of precision medicine, it is important to identify disease-causing mechanisms. Patient specific in vitro modelling of neurological diseases is possible with direct conversion of dermal fibroblasts. This approach may be beneficial for drug discovery studies for rare disorders in the near future.

\section{CONCLUSION}

In conclusion, our study confirmed that human dermal fibroblast can be directly converted into neurons by using small chemicals in vitro. Cellular morphology and gene expression signatures verified this differentiation even at $24^{\text {th }}$ hour of induction.

Acknowledgements: This work was partially supported by Hacettepe University (Grant Number: TAY-2015-7335). We would like to thank Dr. Cem Bayram for SEM visualization (Hacettepe University Advanced Technologies Research and Application Center, HUNITEK, Ankara, Turkey).

\section{REFERENCES}

1. Tsunemoto RK, Eade KT, Blanchard JW, Baldwin KK. Forward engineering neuronal diversity using direct reprogramming. EMBO J 2015; 34:14451455.

2. Takahashi K, Yamanaka S. Induction of pluripotent stem cells from mouse embryonic and adult fibroblast cultures by defined factors. Cell 2006; 126:663-676.

3. Gopalakrishnan S, Hor P, Ichida JK. New approaches for direct conversion of patient fibroblasts into neural cells. Brain Res 2017; 1656:2-13.

4. Yoshihara M, Araki R, Kasama Y et al. Hotspots of De Novo Point Mutations in Induced Pluripotent Stem Cells. Cell Rep 2017; 21:308-315.

5. Ghaffari LT, Starr A, Nelson AT, Sattler R. Representing Diversity in the Dish: Using Patient-Derived in Vitro Models to Recreate the Heterogeneity of Neurological Disease. Front Neurosci 2018; 12:56.

6. Koyanagi-Aoi M, Ohnuki M, Takahashi $\mathrm{K}$ et al. Differentiation-defective phenotypes revealed by large-scale analyses of human pluripotent stem cells. Proc Natl Acad Sci U S A 2013; 110:20569-20574.

7. $\mathrm{Hu}$ W, Qiu B, Guan W et al. Direct Conversion of Normal and Alzheimer's Disease Human Fibroblasts into Neuronal Cells by Small Molecules. Cell Stem Cell 2015 17:204-212.

8. Alyass A, Turcotte M, Meyre D. From big data analysis to personalized medicine for all: challenges and opportunities. BMC Medical Genomics 2015; 8:33.

9. Casamassimi A, Federico A, Rienzo M, Esposito S, Ciccodicola A. Transcriptome Profiling in Human Diseases: New Advances and Perspectives. Int J Mol Sci 2017; 18.

10. Rees MI, Harvey $\mathrm{K}$, Ward $\mathrm{H}$ et al. Isoform heterogeneity of the human 
gephyrin gene (GPHN), binding domains to the glycine receptor, and mutation analysis in hyperekplexia. J Biol Chem 2003; 278:24688-24696.

11. Frischknecht R, Seidenbecher CI. Brevican: a key proteoglycan in the perisynaptic extracellular matrix of the brain. Int J Biochem Cell Biol 2012; 44:1051-1054.

12. Sato S, Omori $\mathrm{Y}$, Katoh $\mathrm{K}$ et al. Pikachurin, a dystroglycan ligand, is essential for photoreceptor ribbon synapse formation. Nat Neurosci 2008; 11:923931.

13. Fogli A, Schiffmann R, Hugendubler L et al. Decreased guanine nucleotide exchange factor activity in eIF2B-mutated patients. Eur J Hum Genet 2004; 12:561566.

14. Fernández-Fernández D, Rosenbrock $\mathrm{H}$, Kroker KS. Inhibition of PDE2A, but not PDE9A, modulates presynaptic short-term plasticity measured by paired-pulse facilitation in the CA1 region of the hippocampus. Synapse 2015; 69:484-496.

15. Cheadle L, Biederer T. The novel synaptogenic protein Farp1 links postsynaptic cytoskeletal dynamics and transsynaptic organization. J Cell Biol 2012; 199:985-1001.

16. Jorge BS, Campbell CM, Miller AR et al. Voltage-gated potassium channel KCNV2 (Kv8.2) contributes to epilepsy susceptibility. Proc Natl Acad Sci U S A 2011; 108:5443-5448.

17. Irwin N, Li YM, O'Toole JE, Benowitz LI. Mst3b, a purine-sensitive Ste20-like protein kinase, regulates axon outgrowth. Proc Natl Acad Sci U S A 2006; 103:18320-18325.

18. Fu MM, Holzbaur EL. MAPK8IP1/JIP1 regulates the trafficking of autophagosomes in neurons. Autophagy 2014; 10:2079-2081.

19. Ito $H$, Mizuno $M$, Noguchi $K$ et al. Expression analyses of Phactr1 (phosphatase and actin regulator 1) during mouse brain development. Neurosci Res 2018; 128:50-57. 